FSM IIImî Araştırmalar Insan ve Toplum Bilimleri Dergisi

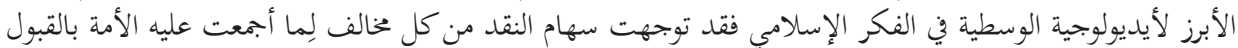

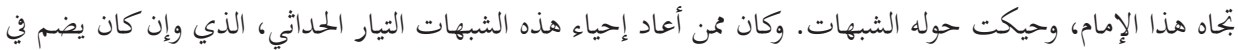

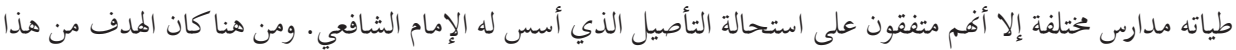

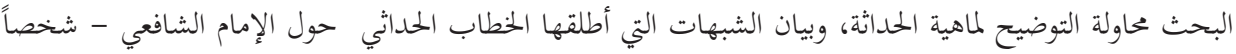

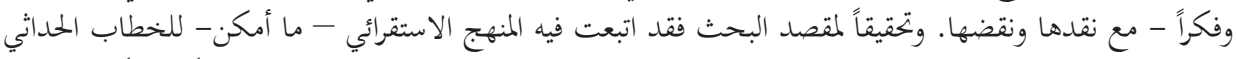

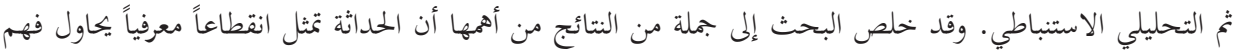

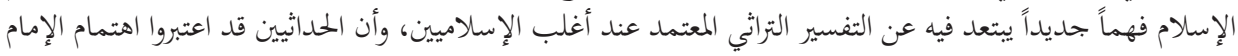

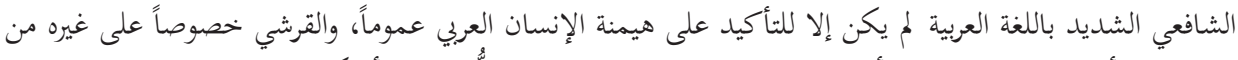

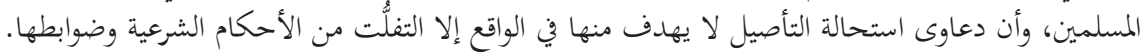

$$
\text { الكلمات المفتاحية: الإمام الشافعي، الحداثة، الشبهات المعاصرة }
$$

$$
\text { د. , جامعة السلطان محمد الفاتح الوقفية ,كلية العلوم الإسلامية ,اسطنبول/ديك رومي }
$$

Dr., Fatih Sultan Mehmet Vakıf Üniversitesi İslami İlimler Fakültesi, İstanbul/Türkiye, ali.m.omari@gmail.com 


\section{Modern Söylemin İmam Şafii Hakkındaki İddiaları}

\section{$\ddot{O} z$}

İmam Şafii düşüncesi , İslam ümmetinde toplumsal bilincin oluşmasına katkıda bulunmuş, İmam Şafii İslam'da itidalli düşüncenin en öne çıkan teorisyeni olmuştur. Bu nedenle ümmetin ittifakla kabul ettiği bu âlime muhalifleri eleştiri oklarını yöneltmekten geri durmamışlar, İmam hakkında birçok farklı iddiayı dile getirmişlerdir. Bu iddiaları yeniden gündeme getiren akımlardan biri de modernizmdir. Modernizm, her ne kadar farklı ekolleri bünyesinde barındırsa da bu ekoller, İslam fikhına İmam Şafii tarafından kazandırılmış usulî kaidelerin vaz'ının, mümkün olmadığı düşüncesinde birleşmektedir. Sözü edilen argümandan hareketle bu araştırmada amaçlanan, modernizmin mâhiyetini açıklamaya çalışmak ve modern söylemin İmam Şafi'ye, şahsî ve fikrî yönden yönelttiği eleştirileri tenkit edip çürütmektedir.

Araştırmada modern söylemin açıklanması bahsinde mümkün olduğunca istikra metodu kullanılmış, diğer kısımlarda ise analitik çözümlemeye başvurulmuştur. Araştırmada pek çok sonuca ulaşılmış olup en önemlileri şunlardır:

-Modernizm, epistomolojik bir kopukluğu temsil etmekte, İslam'1, Müslümanların geneli tarafından itimat edilen geleneksel yorumundan uzaklaşarak yeni bir anlayışla anlamaya çalışmaktadır. -Modernistler, İmam Şafii'nin Arapçaya gösterdiği özenin, genel olarak Arapların, özel olarak da Kureyşlilerin diğer müslümanlar üzerindeki hâkimiyetini vurgulamak amacı taşıdığını düşünmektedirler. -Usûlî kaidelerin vaz'ının imkânsızlığa dair iddialarının, gerçekte şer’î hüküm ve kurallardan kaçmaktan başka bir hedefi olmadığı görülmektedir.

Anahtar Kelimeler: İmam Şafii, modernizm, çağdaş iddialar.

\section{The Claims of Modernists About Imam Ash-Shafi'i}

\section{Abstract}

Since Imam Shafii's thoughts contributed in constituting the principles of thinking for the Islamic nation and he was the most prominent theorist of the moderate ideology in the Islamic thoughts, he has been criticized by every opponents of what the nation has unanimously agreed upon which is the imamate of this Imam.Moreover his opponents fabricated many claims about him. These claims were brought to light again by modernists. Although they apparently follow different schools of thought, they agreed on the impossibility of forming a legal system which was achieved by the Imam. As a result, the objective of this research was to clarify the core of modernism and discover the claims stated by modernists about the Imam - personally and ideologically - then criticize and refute them. Exerting my best efforts to achieve this objective, I adopted the inductive then the analytical deductive approach. Finally, the most important outcomes of this research are: First, Modernism represents a severe epistemological disconnect from the Islamic tradition, and attempts to reinterpret Islam in a manner that does not take into consideration what is necessarily known of the religion. Then, modernists considered that the utmost care of the Imam about the Arabic Language was an evidence of the Arabic hegemony specially the Qurashi one. And finally, the reason behind their claims concerning the impossibility of forming a legal system is to release themselves from the burden of applying the Ahkam( court rulings ) and their authority.

Keywords: Imam Ash-Shafi'i , Modernism, The Claims of Modernists. 


\section{مقدمة}

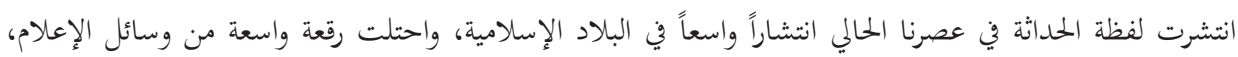

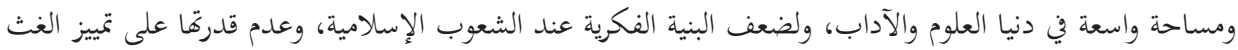

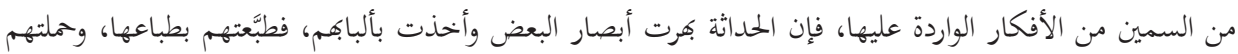

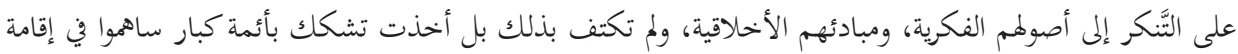

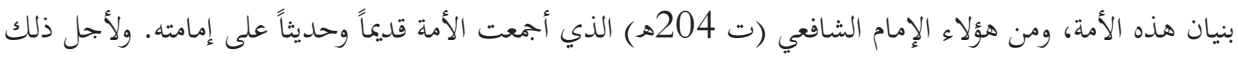

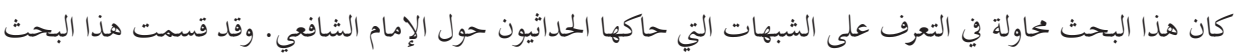
إلى مقدمة وثلاثة فصول: إن مدان الأول: في مفهوم الحداثة

الثاني: في شبهات الخطاب الحداثي حول شخص الإمام الشافعي الثالث: في شبهات الحداثيين حول تأسيس الإمام الشافعي لعلم أصول الفقه.

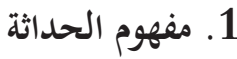

\section{1}

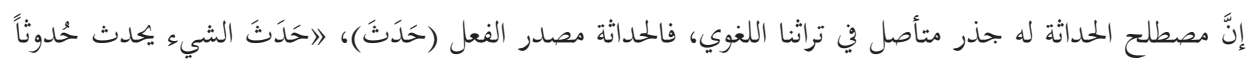

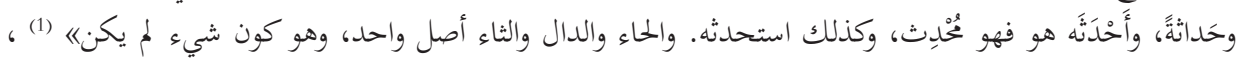

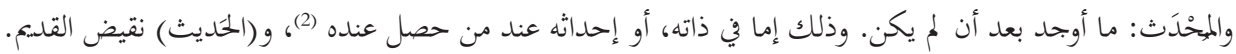

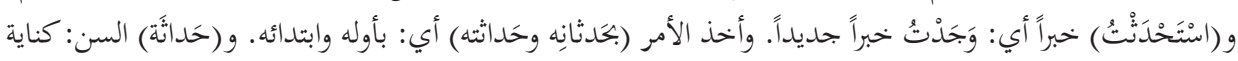

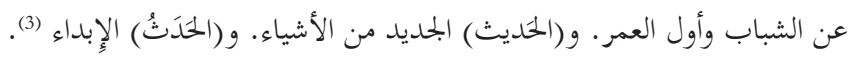

و (الحديث): صفة يوصف بها كل شيء قريب المدة والعهد به (4). والأمر (الحادث): المُنكر غير المعتاد (5). فالحداثة لغةً إذاً تعني: كون الشيء بعد أن لم يكن. والحديث صفيث نقيض القديم. وتعني التجديد والابتداء. وفي اللغة الإنحليزية (الحداثة)

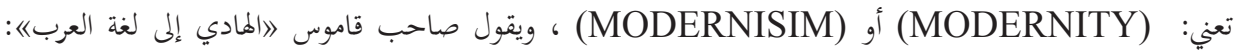

1 ابن فارس، أحمد بن فارس بن زكريا. معجم مقاييس اللغة. تحقيق: عبد السلام محمد هارون. بيروت: دار الجيل. ط2. 1420هـ|

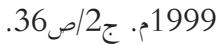

الراغب الأصفهاني، أبو القاسم الحسين بن محمد. المفردات في غريب القرآن. تحقيق: محمد سيد كيلاني. بيروت: دار المعرفة. ط2.

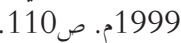

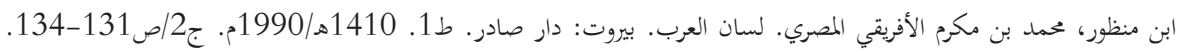
3

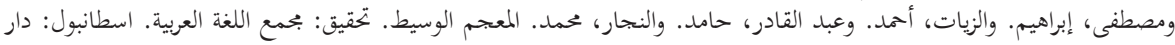

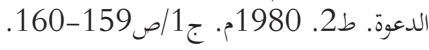
الزبيدي، محمد مرتضى الحسيني. تاج العروس من جواهر القاموس. تحقيق: بحموعة من المحققين. بيروت: دار الهداية. 1385هـ/1965م. 1965. 
الإلحداثة كلمة منقولة عن الكلمة الإنحليزية: (RECENTNESS) أو (MODERNITY) (6) (6) وفي الفرنسية

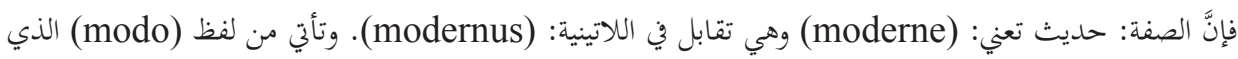

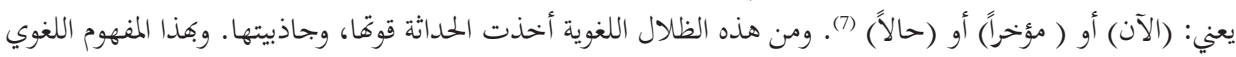

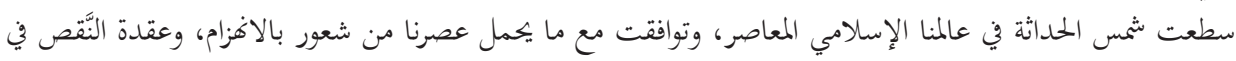

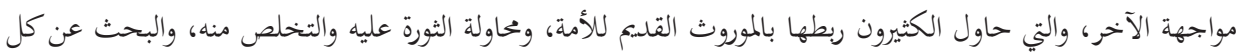

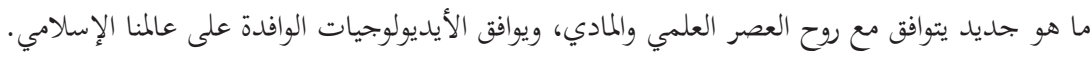

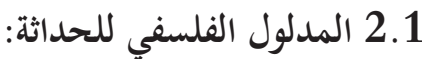

إنَّ مصطلح الحداثة من أكثر المصطلحات غموضاً والتباساً، نظراً لما ينطوي عليه هذا المصطلح من صعوبات معقَّدة بتحله

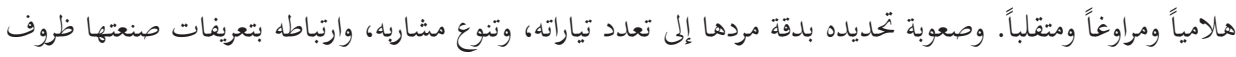

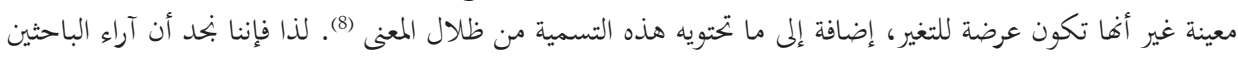

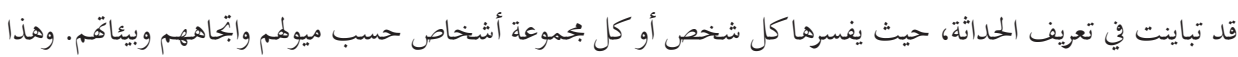

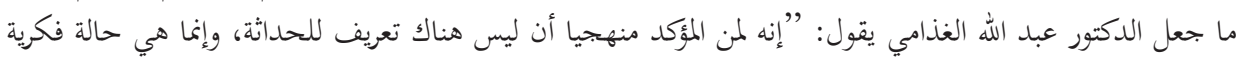

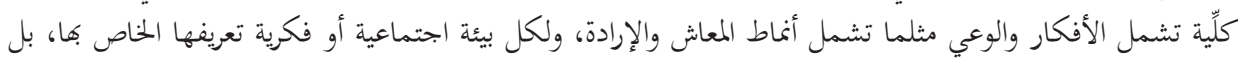

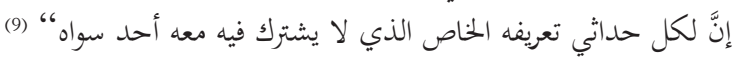

ولسنا نتفق مع الغذامي في عدم وجود تعريف للحداثة، ولكننا نتفق معه في صعوبة هذه المهمة. لذلك سنعرض بشكل

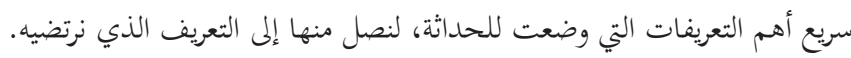

يعرف عبد المحيد الشريف الحداثة بأها: "مفهوم مستعمل للدلالة على المميزات المشتركة بين البلدان الأكثر تقدماً في بحال

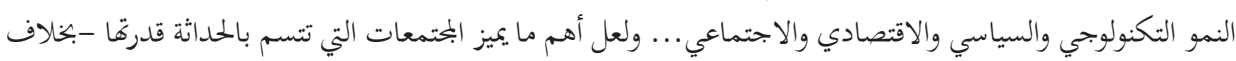
المختمعات التقليدية- على الابتكار والتغيير، (10).

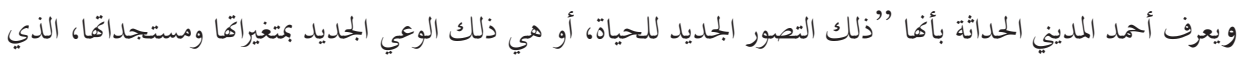

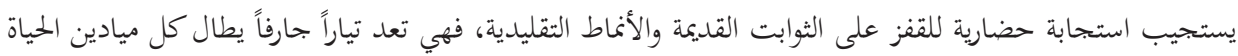

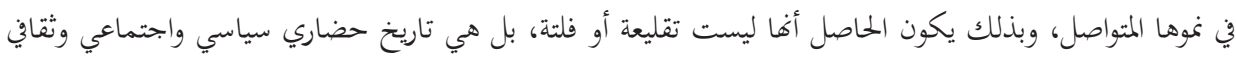
فلسفي وإبداعي"،

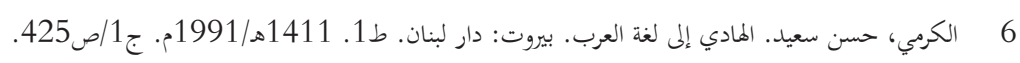

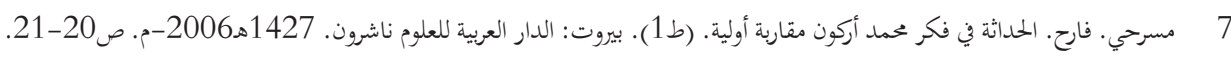

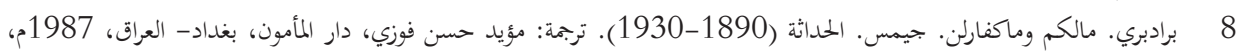

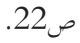
الغذامي. عبدالله محمد. حكاية الحداثة في المملكة العربية السعودية. المركز الثقافي العربي، الدار البيضاء- المغرب/بيروت- لبنان، ط2،

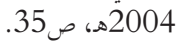

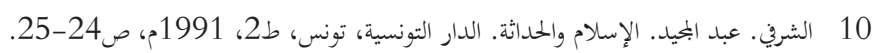

11 المديني. أحمد. الصمت- الحداثة، عزلة النص وهرطقة التنظير، الحداثة الأخرى. بحلة كتابات معاصرة، بيروت-لبنان، بحلد 
ويقول إبراهيم القهوايجي: اإنما ضمن أبسط المفاهيم: الاتساق مع العصر والضرورة والحاجة، وهي في حركة تطور وتقدم

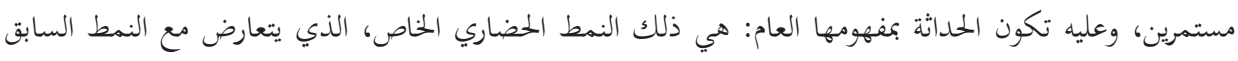
عليه"،

يلاحظ من التعريفات الثلاثة السابقة أفها لم تعرِّف جوهر الحداثة وماهيتها، وإنما أظهرت بعض مظاهرها في البحتمع

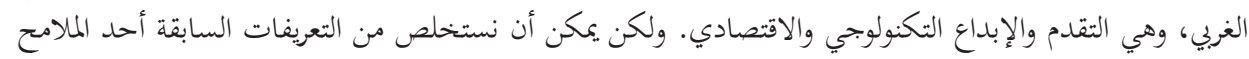

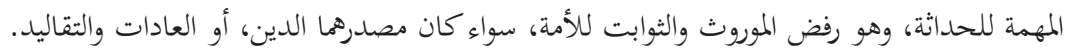

وهذا ما يؤكده كمال أبو ديب بقوله: 》ا الحداثة انقطاع معرفي؛ ذلك أن مصادرها المعرفية لا تكمن في المصادر المعرفية

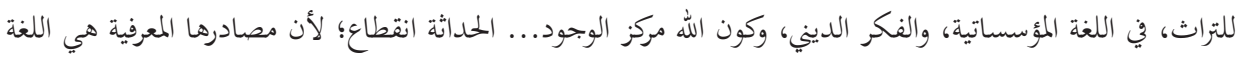
البكر، والفكر العلماني، وكون الإنسان مركز الوجودها (13).

فكمال أبو ديب يعزو تمرد الحداثة على التراث -أو الانقطاع المعرفي كما يسميه- إلى اختلاف المصادر المعرفية لكل

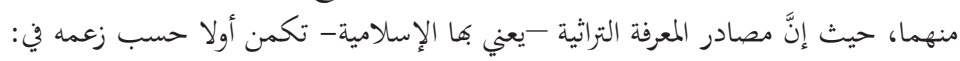

أولاً: اللغة المؤسساتية، ويعني بها اللغة التي تخضع للقواعد الوضعية التي اتفق أهل اللغة عليها. وعوضِا عنها، فئها، فإنَّ الحداثة

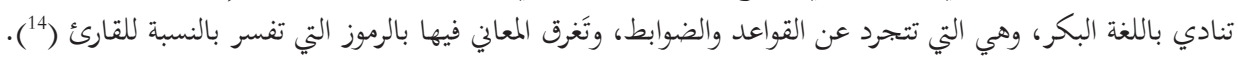
ثانيا: الفكر الديني، أو تسيير شؤون الحياة بما يتوافق مع الدين، وهو ما ترفضه الحداثة جملة وتفصيلا، وتنادي بضرورة فصل الدين عن الدولة.

ثالثا: أن الله تعالى هو مركز الوجود، أي الله تعالى هو المتصرف وحده بالكون، والإنسان لا يستطيع أن يوجد شيئا

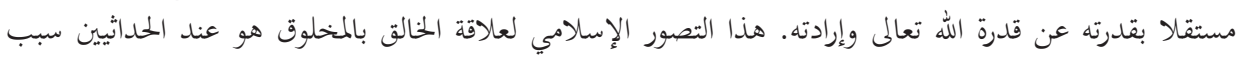

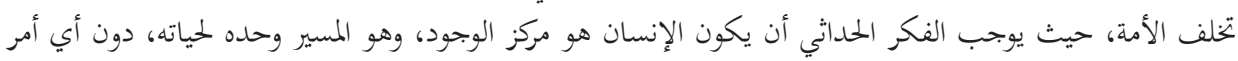
خارج عنه.

ويرتقي جابر عصفور بالمفهوم الفلسفي للحداثة فيقول: اإنها حالة وعي متغير، يبدأ بالشك فيما هو قائم، ويعيد

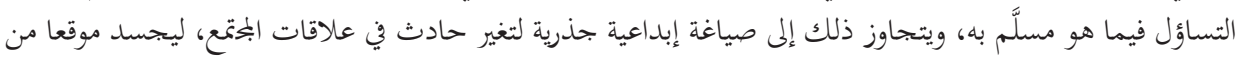

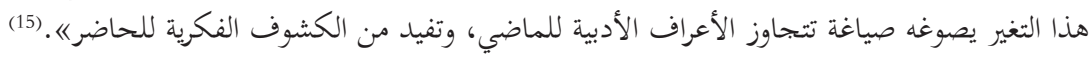
وتقترب خالدة سعيد من التعريف السابق فتقول: \ا الحداثة وضعية فكرية، لا تنفصل عن ظهور الأفكار والنزعات

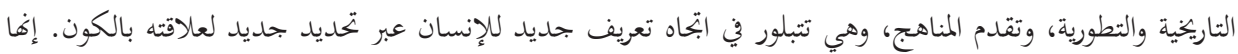

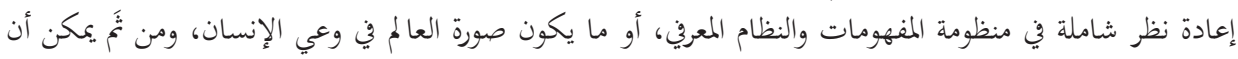

http://www.middle-east-online. القهوايجي. إبراهيم. تأملات في الحداثة العربية الأدبية. مقالة منشورة على موقع: $\mathrm{com} /$ ?id=29448

أبو ديب، كمال. الحداثة،السلطة،النص. بحلة فصول، الميئة المصرية العامة للكتاب، القاهرة-مصر، بحلد4، العدد3، 1984م، 1984م، ص37.

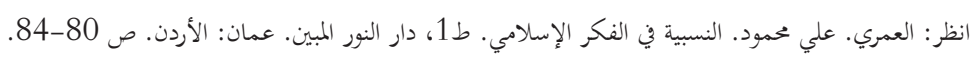

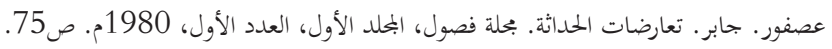


يقال: إنما إعادة نظر في المراجع والأدوات والقيم والمعاييره. (16). من التعريفات السابقة يمكن أن نخلص إلى أنَّ الحداثة العربية ببساطة، ودون التعقيد والتقعر والغموض الذي يحاول

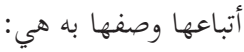
محاولة إعادة فهم الإسلام فهما جديدا، لا يعتمد على المدلول اللغوي المتواتر للنص القرآي، بل على ما تحمله اللغة

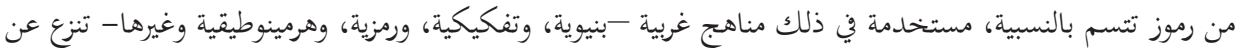

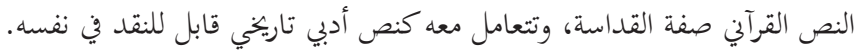

\section{2 شبهات الخطاب الحداثي حول شخص الإمام الشافعي}

إن الباحث في نظرة الحداثيين العرب إلى الإمام الشافعي سيجد أن سهام النقد الحداثي توجهت إلى شخص الإمام

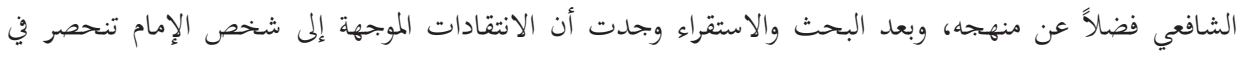
قضيتين اثنتين هما:

الأولى: استغلاله النسب القرشي في تثبيت أفكاره، بالإضافة إلى توجهه العروبي لا الإسلامي. الثانية: تعاونه مع نظام الحكم في حين عزف عن ذلك سائر الأئمة الأربعة. وسنحاول في هذا الفصل التعرض بشكل موجز لككال القضيتين

\section{2}

أولى الإمام الشافعي أهمية قصوى للغة العربية في فقهه وأصوله، وكان له أيضاً في قضية عربية القرآن موقف متميز. هذا

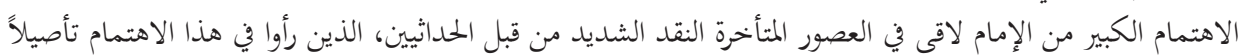
للعنصرية والقبلية التي جاء الإسلام بمحاربتها.

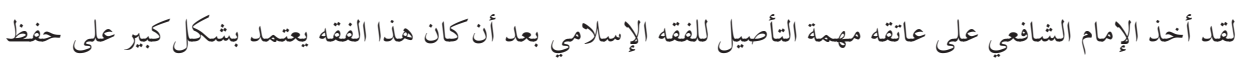

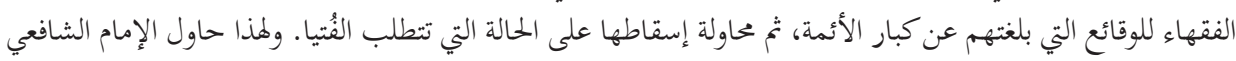

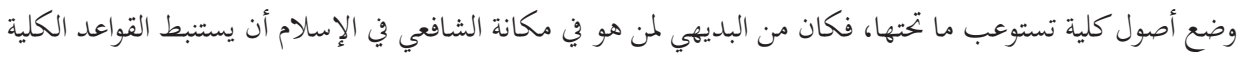

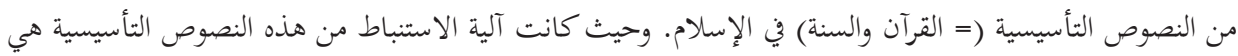

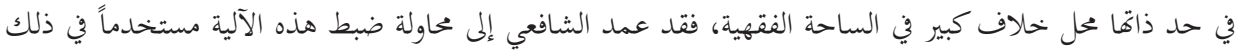

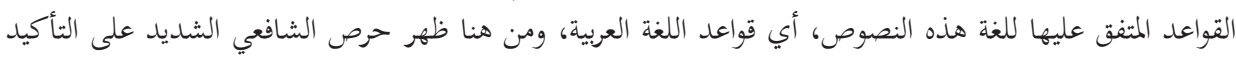

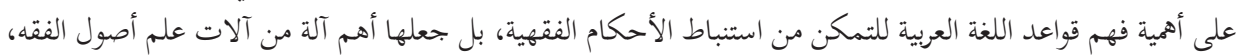

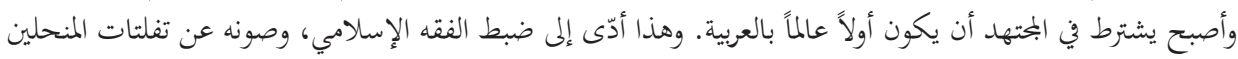

والمتنطعين على حد سواء.

ومن النقطة الأخيرة بالذات يمكن أن نفهم لماذا تعرض الشافعي للنقد الشديد من أرباب الحداثة، حيث بينا في الفصل

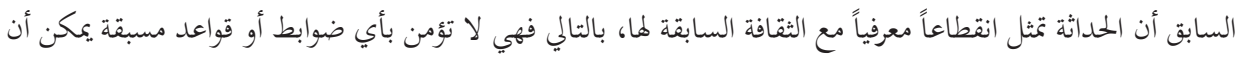


تسيّر عملية الفكر الإنساني، وفي هذا يقول كمال أبو ديب: 》ا إن مصادر الحداثة المعرفية لا تكمن في المصادر المعرفية

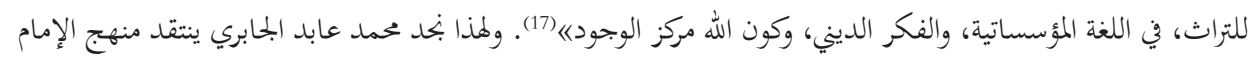

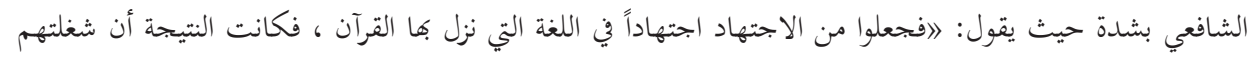

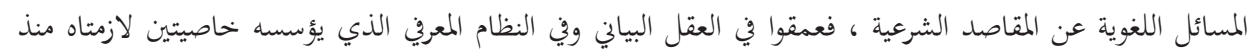

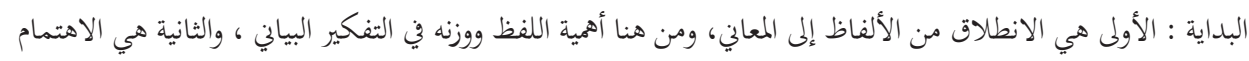

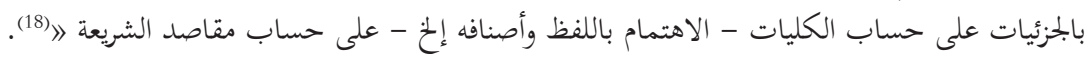

ولاشك أن هذا الككلام فيه الكثير من المغالطات، فالانتقال مثلاً من اللغة إلى الواقعة المحددة في الفقه هو من باب الانتقال

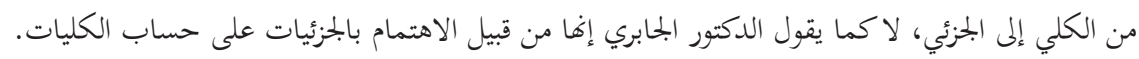
ولم يكتف الحداثيون بانتقاد الشافعي لشدة اهتمامه باللغة العربية، بل اعتبروا هذه النقطة مطية لتوجيه النقد لشخص

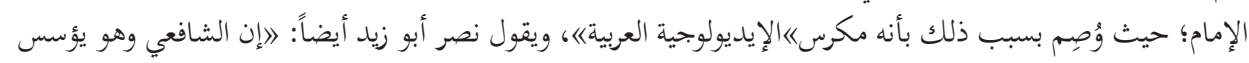

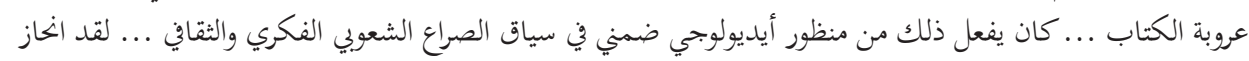
إلى العروبة فقط بل إلى القرشية تحديداً (19).

وبما أن نصر حامد أبو زيد كان من أبرز من وجه النقد لشخص الشافعي يحسن بنا في هذا المبحث أن نخصص اتقاماته

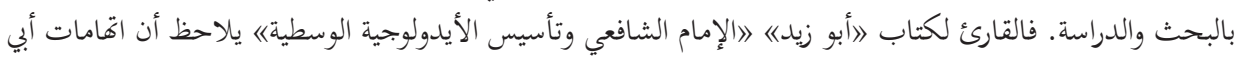

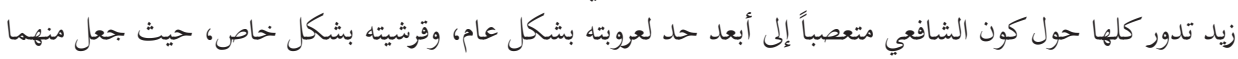

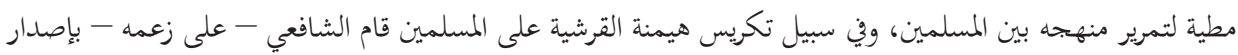

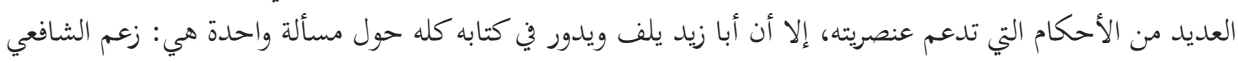

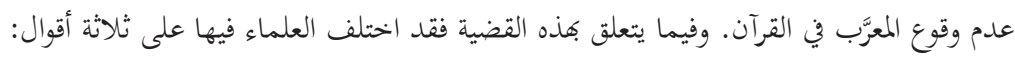
القائلين بوجود المعرَّب في القرآن، والقائلين بنفي ذلك، والمتوسطين في هذه المسألة.

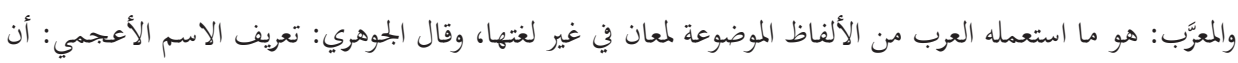

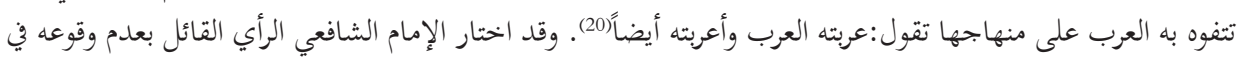

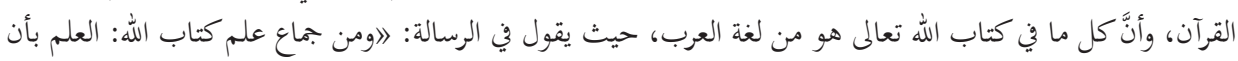

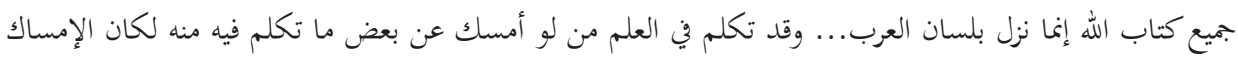

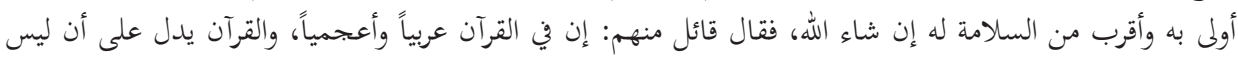
من كتاب الله شيء إلا بلسان العربه (21).

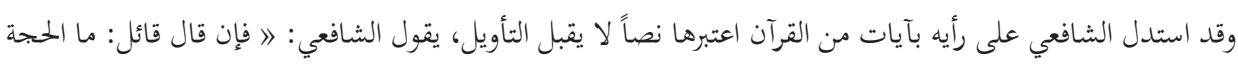

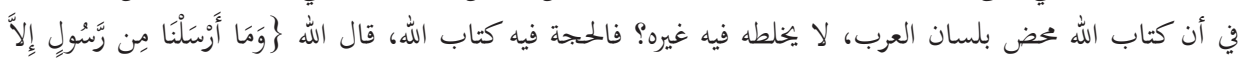

17 أبو ديب، كمال. الحداثة،السلطة،النص. بحلة فصول. ص37.

18 الجابري، محمد عابد. بنية العقل العربي. مركز دراسات الوحدة العربية. 2010. 19

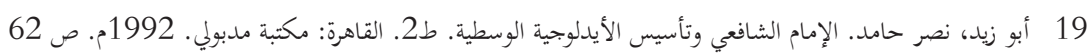

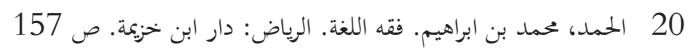

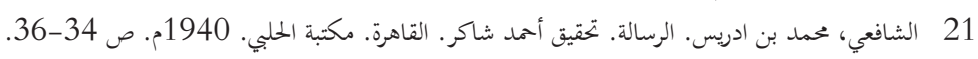




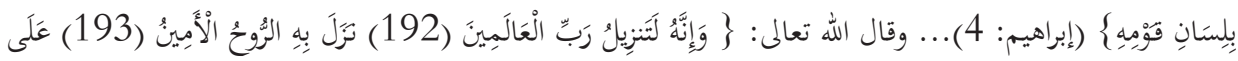

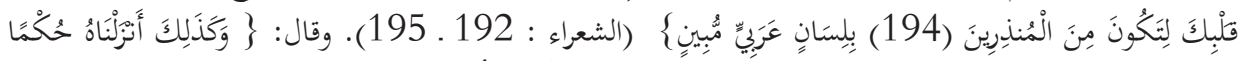

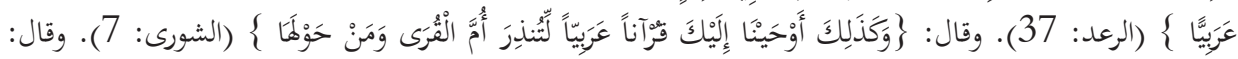

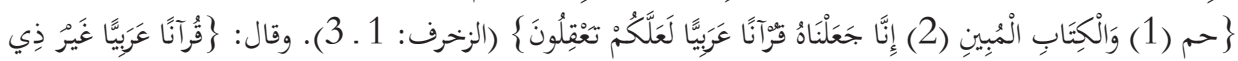

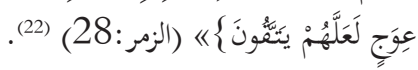

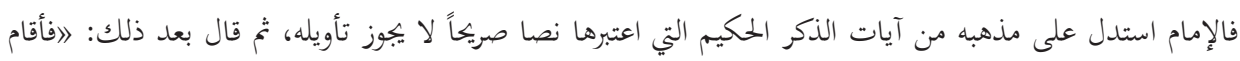

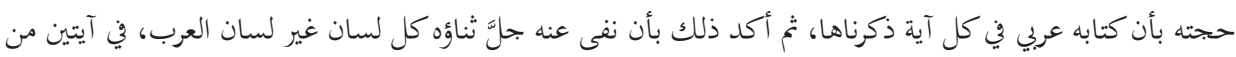

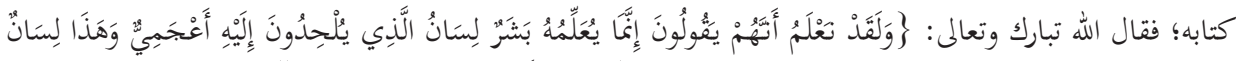

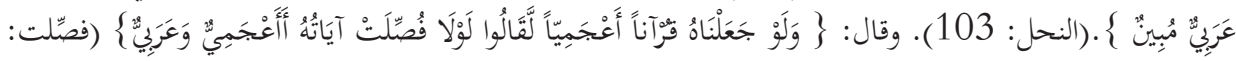
.23) .» (44

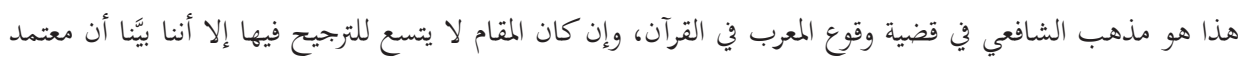

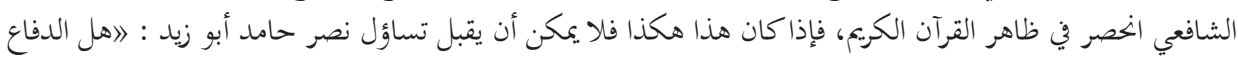

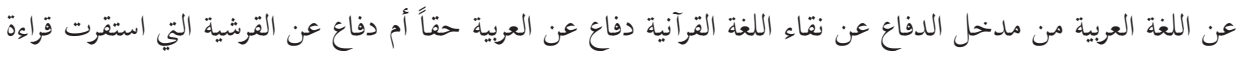
القرآن على القراءة بلهجتها؟ي/24).

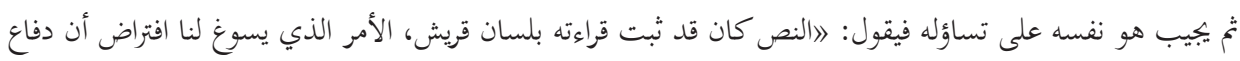

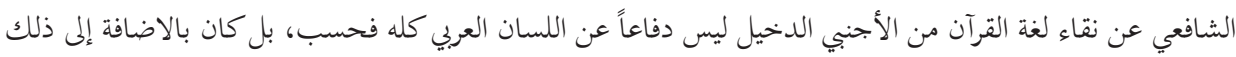

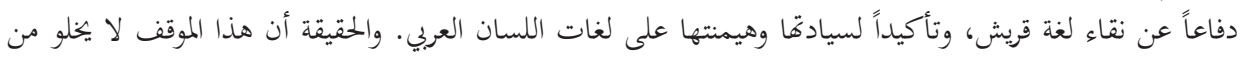

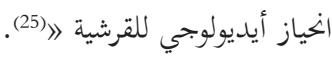

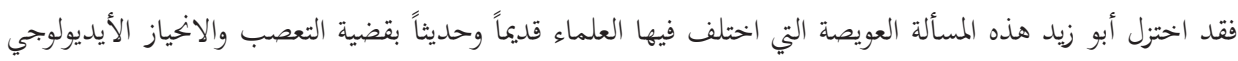

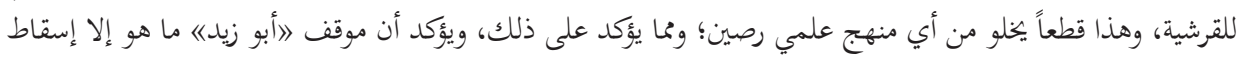

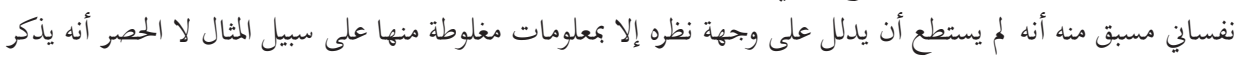

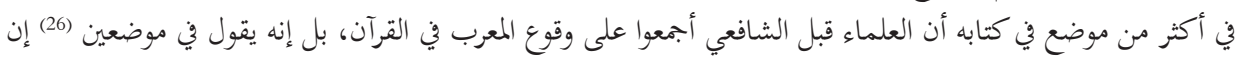

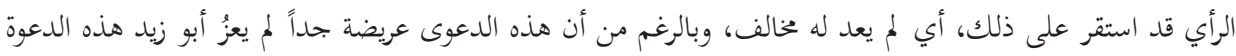

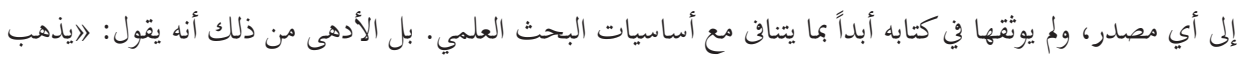

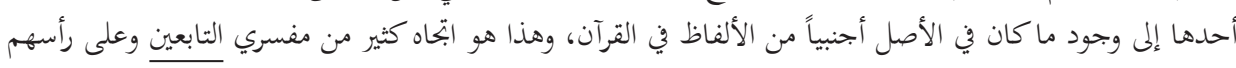

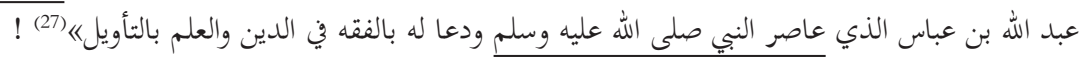

$$
\begin{aligned}
& 22 \text { الشافعي، محمد بن ادريس. الرسالة ، ص-39 } 41 . \\
& 23 \text { المرجع السابق، ص } 41 . \\
& 24 \text { الإمام الشافعي وتأسيس الايدولوجيا الوسطية، ص44. لمب. }
\end{aligned}
$$

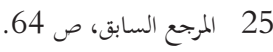

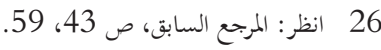

$$
\begin{aligned}
& 27 \text { المربع السابق، ص المرابع، صـ } 60 .
\end{aligned}
$$


على أن الزركشي ينسب قول الشافعي إلى الجمهور - بخلاف ما يدعي أبو زيد - فيقول في البرهان: اهذا مذهب

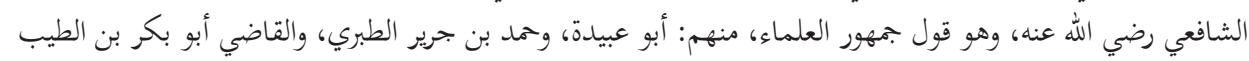

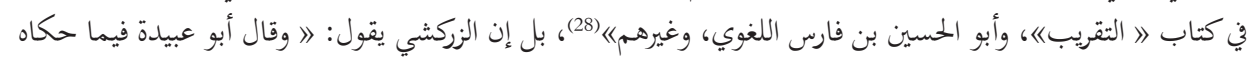
ابن فارس: إنما أنزل القرآن بلسان عربي مبين ، فمن زعم أن فيه غير العربية فقد أعظم القولهي (29).

\section{2}

يقول الدكتور أبو زيد: 》الكن أهم صور التعبير عن انحياز الشافعي للقرشية أنه الفقيه الوحيد من فقهاء عصره الذي تعاون

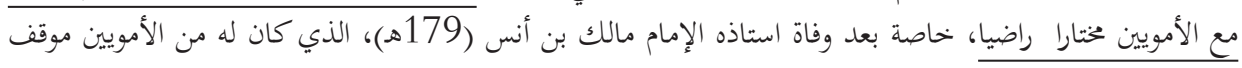

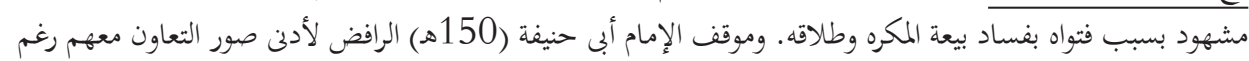

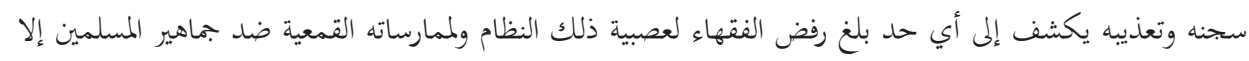

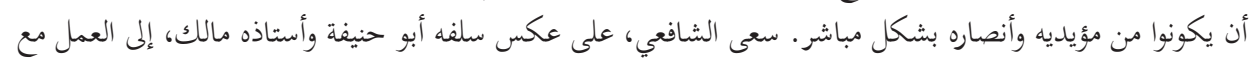

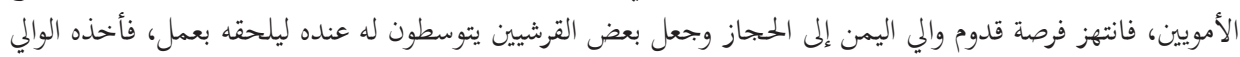

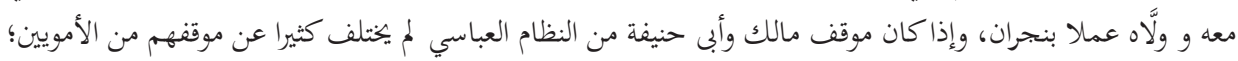

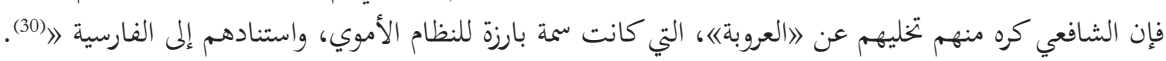
وهذه الدعوى لهي غريبة حقاً خصوصاً من أستاذ جامعي أكاديمي؛ فكيف يدعي الدكتور نصر أبو زيد أن الإمام الشافعي

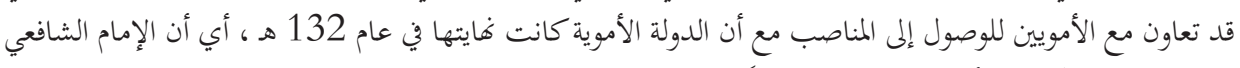

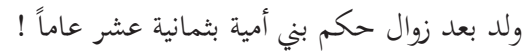

وحاول أبو زيد الدفاع عن نفسه فقال في كتابه الصادر بعد ثناث سنوات من كتابه عن الشافعي ما نصه: اولعل هذا

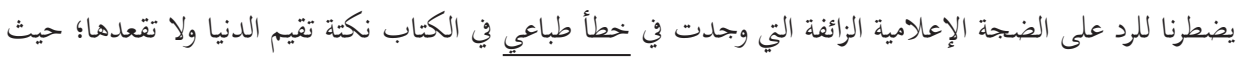

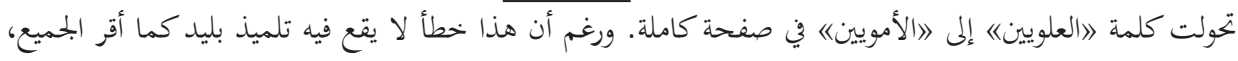

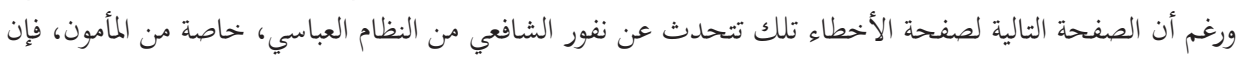

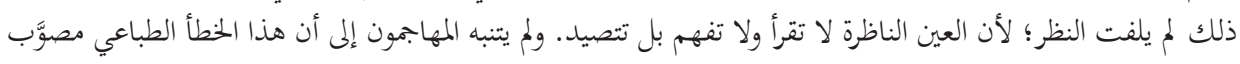
في ثبت التصويبات في آخر الكتابه(31).

ويصعب للباحث أن يسلم لأبي زيد بأنه خطأ مطبعي لعدة أسباب؛ أولها أن الطبعة الأولى من الكتاب لا يوجد بها

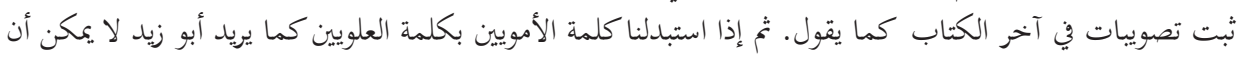

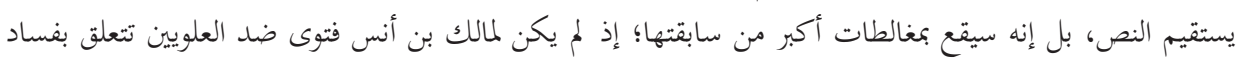

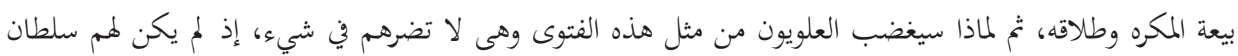

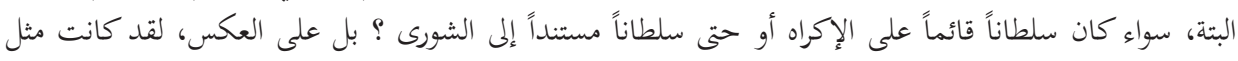

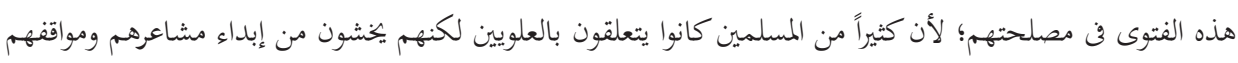

28 الزركشي، بدر الدين محمد بن عبد الله. البرهان في علوم القرآن. بيروت: دار المعرفة. 1990م. 1 / 382.

29

30 أبو زيد، نصر حامد. الإمام الشافعي وتأسيس الأيدلوجية الوسطية. الطبعة الأولى. القاهرة: دار ابن سينا. 1992م.

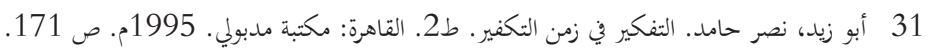


تحاههم كما هو معروف. كذلك لم يكن للعلويين سلطان في اليمن، فكيف يوسط الشافعي أحدهم كي يعينوه في

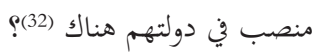

ثم إن أبو زيد يقول: 》ا لكن أهم صور التعبير عن انحياز الشافعى للقرشية أنه الفقيه الوحيد من فقهاء عصره الذى تعاون

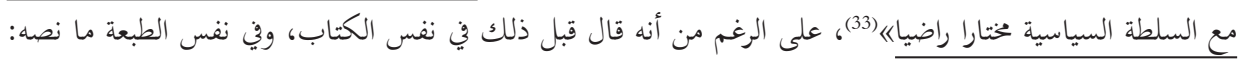

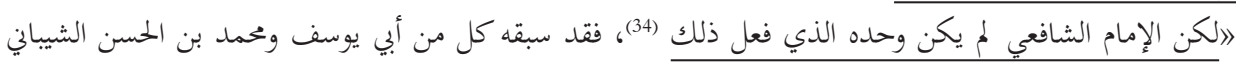
تلميذي أبي حنيفة/(35). فتأمل في التناقض الصامن وحلده الذي فعل ذلك فيما تحته خط في كلا النصين.

\section{3. شبهات الحداثيين حول تأسيس الإمام الثافعي لأصول الفقه}

إن عملية التأصيل، وضع الأصل، لا تتم بشكل فردي، إنما تحتاج بنية ثقافية موضوعية لتأسيسها، بيد أنه قد تتجلى في

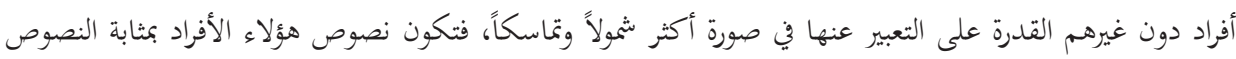

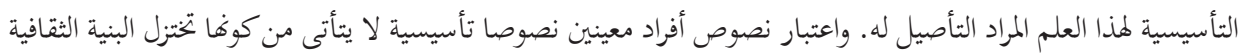

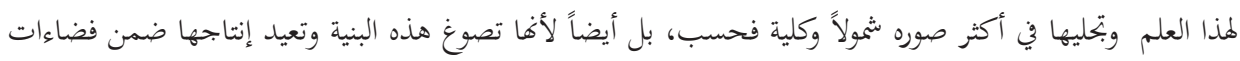

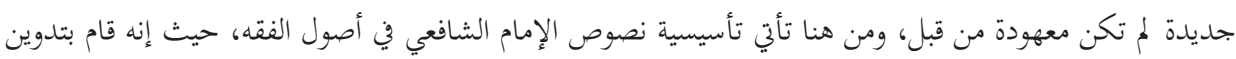

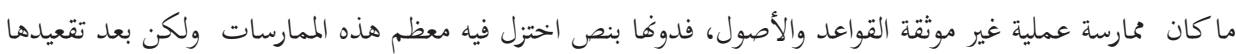

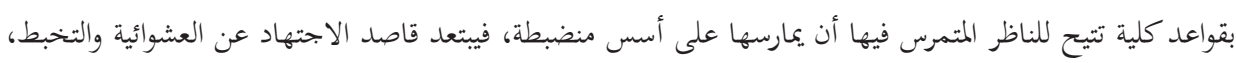

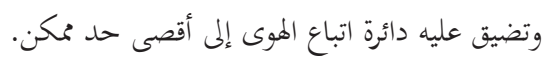

وإذا كان هذا هكذا، فحريٌ أن ينال بجهود الشافعي الثناء الموصول من المفكرين الذين ينظرون ليلاً وهماراً بضرورة إعمال

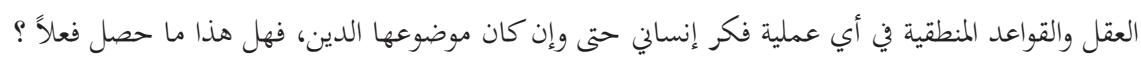
من يمعن النظر في الخطاب الحداثي يدرك بلا شك أن مفهوم التأصيل هو ألد أعداء الحداثة؛ لأهما تقوم بشكل أساسي

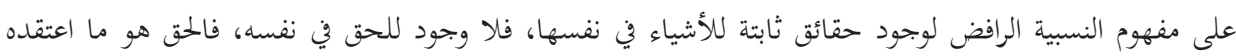

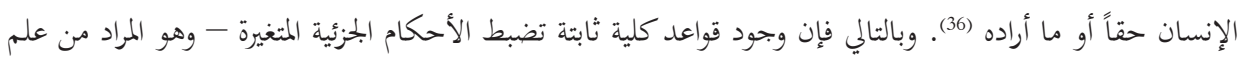

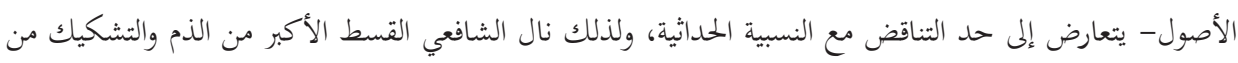
قبل الحداثيين؛ فهو في نظرهم كان يناضل اللقضاء على التعددية الفكرية والفقهية، وهو نضال لا يخلو من مغزى

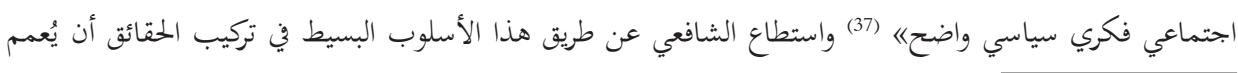

32

VtYlfOCAldA

$$
\begin{aligned}
& 33 \text { الإمام الشافعي وتأسيس الأيدولوجيا الوسطية. ص } 62 . \\
& 34 \text { أي تعاونه مع السلطة السياسية. } 333 \\
& 35 \text { المرجع السايق، ص } 36 \\
& 36 \text { انظر: النسبية في الفكر الاسلامي صلمان } 36
\end{aligned}
$$

37 أبو زيد، نصر حامد، الإمام الشافعي وتأسيس الأيديولوجيا الوسطية، ص 101. 101. وانظر: عمارة، محمد. التفسير الماركسي للإسلام.

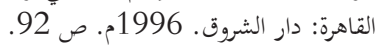


الصيغ والقوالب الثيولوجية الشعبوية العنيدة والرازحة، ويجعلها فاعلة ومؤثرة حتى يومنا هذا (38)، وهو الذي ابتدأ في

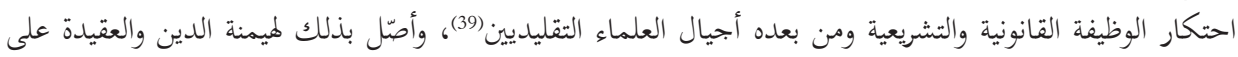

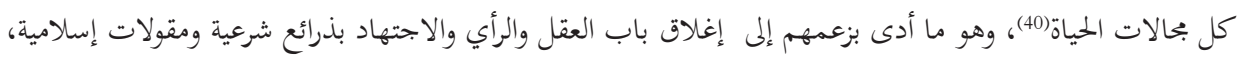

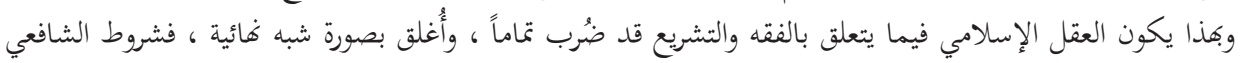

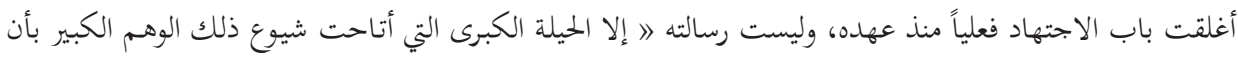
الشريعة ذات أصل إلهي《(41).

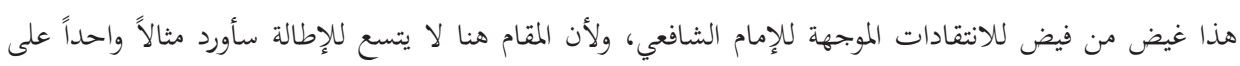

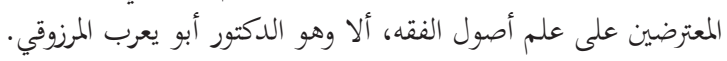

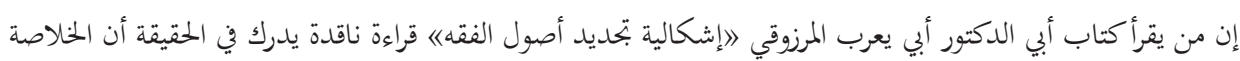

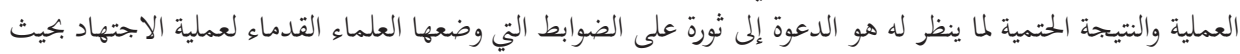
تتسم الشريعة بالنسبية.

فهو مثلاً يعترض على عملية التأصيل لأفها بزعمه 》جعلت التشريع في الواقع وضعياً وضعاً فاسداً) (42) ولكن كيف ذلك؟ عملية التأصيل في نظر المرزوقي لاهي وضع فاسد من رؤساء المدارس الفقهية الذين اغتصبوا سلطة التشريع من الأمة

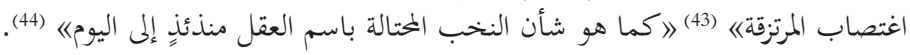

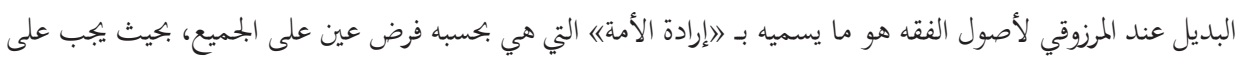

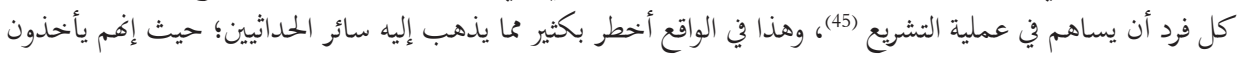

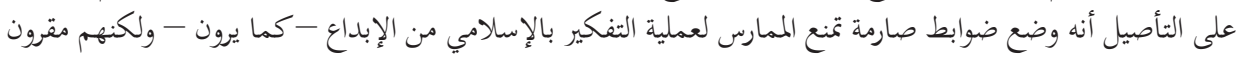

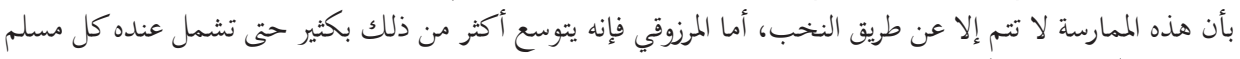

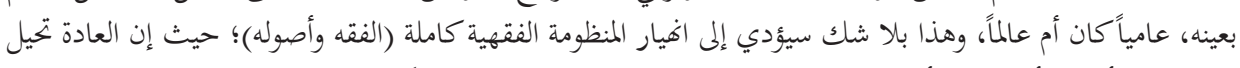

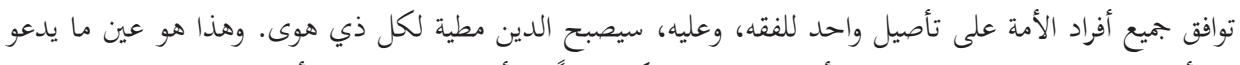

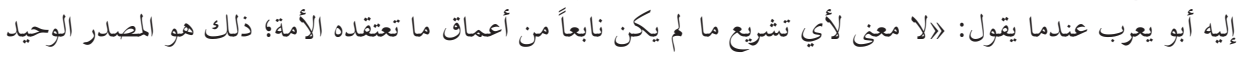

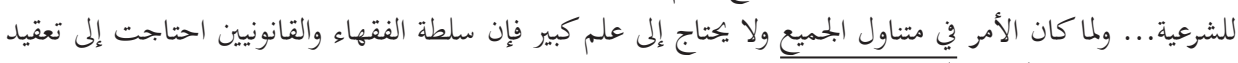

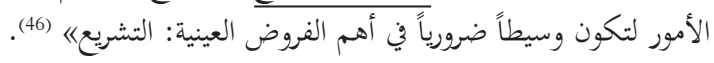
ويرى أن 》عملية السطو التي خطط لها الشافعي على إرادة الأمة/ أدت إلى 》القياس بتعليل الأحكام إلى حد التسيب

$$
\begin{aligned}
& 38 \text { أركون، محمد. تاريخية الفكر العربي الإسلامي. الرباط: المركز الثقافي العربي. 1998م. ص } 73 \text {. }
\end{aligned}
$$

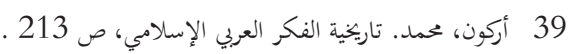

$$
\begin{aligned}
& 40 \\
& 41
\end{aligned}
$$

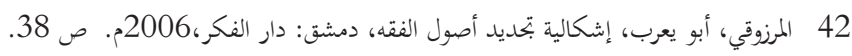

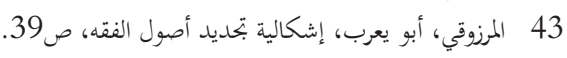

$$
\begin{aligned}
& 44 \\
& 45 \\
& 46 \text { المرجع السابق، ص } 106 .
\end{aligned}
$$


المطلق في غايته التي تتجاوز التعليل المعين إلى التعليل بالمقاصد عامة، ومنها يستمد الفقيه، الذي بات المشرع الفعلي،

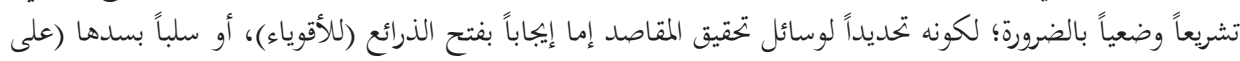

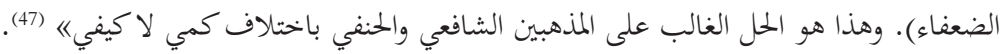

فالمرزوقي يزعم أن غاية القياس عند الأصوليين هي التوسع في التعليل بالمقاصد، وهذا بلا شك يدل على أمرين: الأول

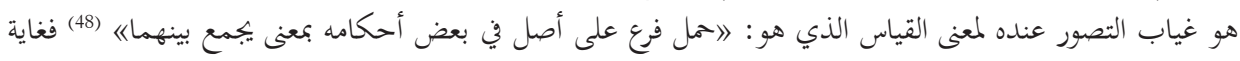
القياس عند الأصوليين هي إجراء حكم الأصل على الفرع، وهذا لا يتم إلا بضوابط صارمة مبثوثة في كتب اصب على علم الأصول. الثاني: التجني وإطلاق التهم جزافاً، لاسيما قوله: "وهنا يصبح الرأي الفاسد، أو المعرفة الغفل بما يسمونه مقاصد وعلاً

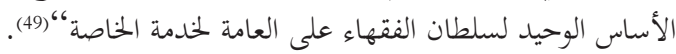

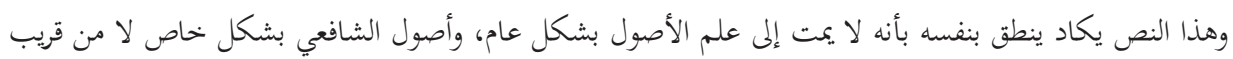

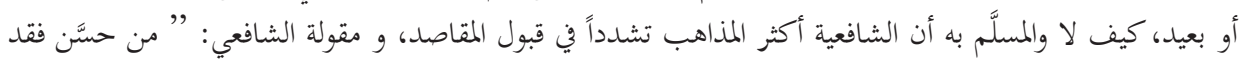
شرع" صريحة في هذا.

تم أين هذا الدعوى العريضة من كلام الشافعي في رسالته إذ يقول: "ولا يقيس إلا من جمع الآلة التي له القياس بها،

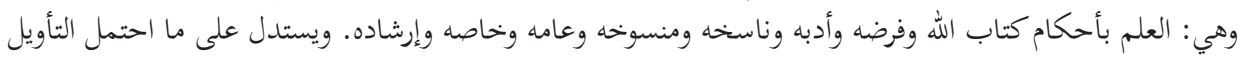

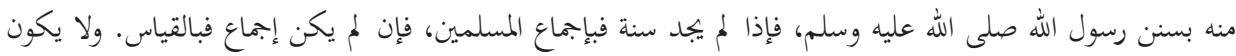

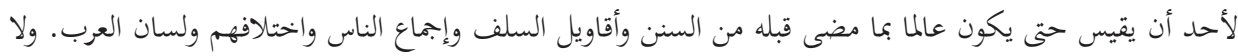

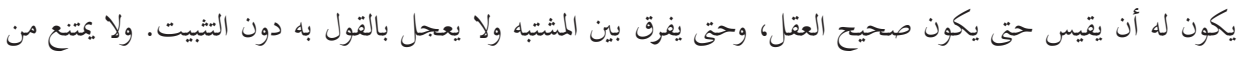

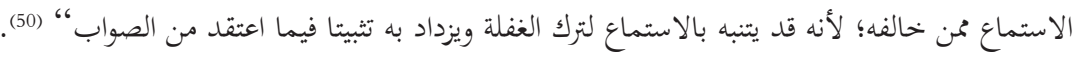

\section{الخحاتمة}

إذا كانت فلسفة الحماثة العربية تحديداً تعتمد على الانقطاع المعريف مع التراث، فإنه بلا شك سيكون من أهم معاركها

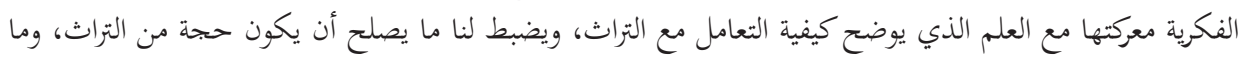

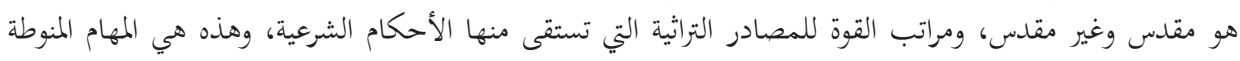
بعلم أصول الفقه.

ولما كان واضع هذا العلم هو الإمام الشافعي، فإن التيار الحداثي تناوله بالنقد، سواء كان النقد موجها لشخصه (في

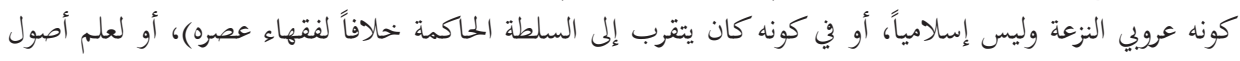
الفقه الذي وضعه.

وقد بينا في ثنايا هذا البحث أن الشبهات التي تناولت شخصه قد اتسمت المغالطات التاريخية، كما أن الانتقادات التي تناولت علم أصول الفقه كانت لا منهجية على الأغلب.

$$
\begin{aligned}
& 47 \\
& 48 \text { الشيرازي، أبو إسحاق. اللمع في أصول الفقه. بيروت: دار ابن كثير. ط2. }
\end{aligned}
$$

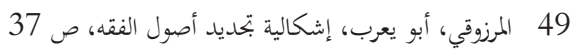

$$
\begin{aligned}
& 50
\end{aligned}
$$




\section{المراجع}

ـ أركون، محمد. تاريخية الفكر العربي الإسلامي. الرباط: المركز الثقافي العربي. 1998م.

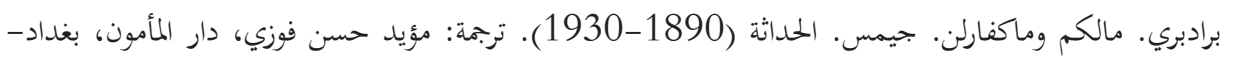

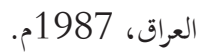

$$
\text { الحابري، محمد بن ابراهيم. فقه اللغة. الرياض: دار ابن خزيكة. }
$$

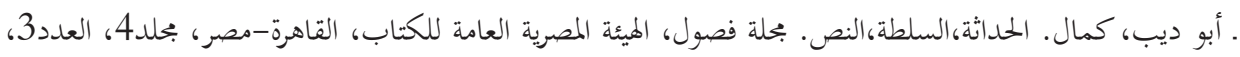
1984م.

. الراغب الأصفهاني، أبو القاسم الحسين بن محمد. المفردات في غريب القرآن. تحقيق: محمد سيد كيلاني. بيروت: دار المعرفة. ط2. 1999م الإطفي أبر

الزبيدي، محمد مرتضى الحسيني. تاج العروس من جواهر القاموس. تحقيق: بجموعة من المقققين. بيروت: دار المداية. 1385هـ/1965م. شيدم مرتض . الزركشي، بدر الدين محمد بن عبد الله. البرهان في علوم القرآن. بيروت: دار المعرفة. 1990م.

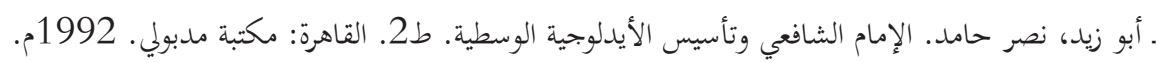

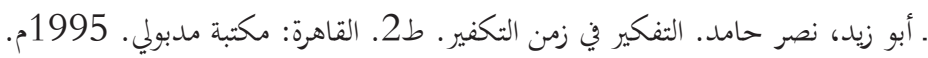
. سعيد، خالدة. بحلة فصول، المحلد الرابع، العدد الثالث، 1984. الشافعي، محمد بن ادريس. الرسالة. تحقيق أحمد شاكر . القاهرة. مكتبة الحبلي. 1940م.

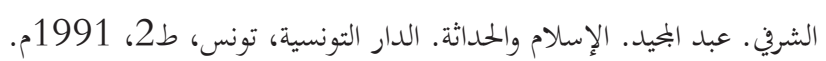

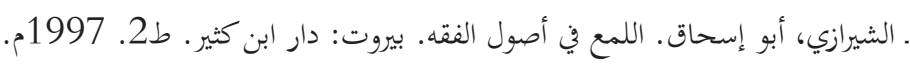

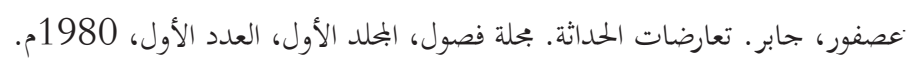

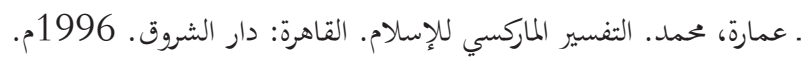
العمري، علي محمود. النسبية في الفكر الإسلامي. ط1، دار النور المبين. عمان: الأردن.

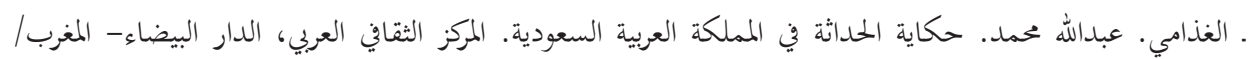
بيروت- لبنان، ط2، 2004 200ده

• ابن فارس، أحمد بن فارس بن زكريا. معجم مقاييس اللغة. تحقيق: عبد السلام محمد هارون. بيروت: دار الجيل. ط2 طو.

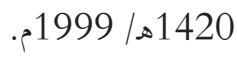
الكرمي، حسن سعيد. المادي إلى لغة العرب. بيروت: دار لبنان. ط1. 1411هـ/1991م. 


$$
\text { ـ مبروك، علي. ما وراء تأسيس الأصول. القاهرة: دار رؤية. 2007م. }
$$

مسرحي. فارح. الحداثة في فكر محمد أركون مقاربة أولية. ط1. بيروت: الدار العربية للعلوم ناشرون. 1427هـ2006

· المديني. أحمد. الصمت- الحداثة، عزلة النص وهرطقة التنظير، الحداثة الأخرى. بملة كتابات معاصرة، بيروت-لبنان، حدرة بحلد5، العدد15، حزيران 1993. ـ المرزوقي، أبو يعرب، إشكالية بتحيد أصول الفقه، دمشق: دار الفكر،2006م. ـ مصطفى، إبراهيم. والزيات، أحمد. وعبد القادر، حامد. والنجار، محمد. المعجم الوسيط. تحقيق: بحمع اللغة العربية.

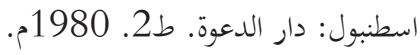
ـ ابن منظور، محمد بن مكرم الأفريقي المصري. لسان العرب. بيروت: دار صادر. ط1. 1410هـ/1990م. 
Arkon, Muhammed, Târihiyyetu'l-fikri'il-İslâmî el-“Arabî, er-Ribât, el-Merkez es-Skâfî el-'Arabî, 1998.

Biradbiri, Malkom ve Makfârilin Ceymis, el-Hadâse (1890-1930) tercüme: Müeyyed Hasan Fevzî, Dâru'l-Me'mûn, Bağdâd-el-İrâk, 1987.

el-Hamed, Muhammed b. İbrahim, fikh'l-luğa, er-Riyâd: Dâr İbn Huzeyme.

El-Câbirî, Mihammed b. Âbid, Binyetu'l-akli'l-Arabî, Merkez dirâsât el-vahdeti'l-Arabiyye, 2010.

Ebû dîb, Kemâl, el-Hadâse,es-Sulta, en-Nas, Mecelletu fusûl, el-Hey'et-elMisriyye el-'amme li'l-kit'ab, el-Kahira-Misır, mucelled 4, el-aded 3, 1984.

Er-Rağıb el-Isfahânî, Ebu'l-Kâsım el-Huseyn b. Muhammed, el-Mufredât fî̀ Ğarîbi'l-Kur'ân, tahkik: Muhammed Seyyid Keylânî, Beyrut, Dâru'l-Marife, 1999.

Ez-Zebîdî, Muhaammed Murtezâ el-Huseynî, Tâcu'l-Arûs Min Cevâhiri'l-Kâmûs, tahkik: Mecmâtun mine'l-Muhakkikîn, Beyrut, Dâru'l-Hidâye, 1965.

Ez-Zerkeşî, Bedruddin Muhammed b. Abdillah, el-Burhân fî 'Ulûmi'l-Kur'ân, Beyrut, Dâru'l-Ma'rife, 1990.

Ebu Zeyd, Nasr Hamid, el-İmâm eş-Şâfi'î ve Te'sîs el-eydilûciyye el-vasatiyye, el-Kahira, Mektebetu medbûlî, 1992.

Ebu Zeyd, Nasr Hamid, et-Tefkîr fî zemen et-Tekfîr, el-Kahira, mektebetü Medbûlî, 1992.

Saîd, Hâlide, Mecelletu Fusûl, el-mucelled er-râb'i, el'aded es-sâlis, 1984.

Eş-Şâfi'î, Muhammed İdris, er-Risâle, tahkik: Ahmed Şakir, el-Kâhira, Mektebetu'l-Halebî, 1940.

Eş-Şerafu, Abdulmecid, el-islâm ve'l-Hadâse, ed-Dâru't-Tûnusiyye, Tunus, 1991.

Eş-Şîrâzî, Ebû İshâk, el-Lume’ fî̀ Usûli’l-F1kh, Beyrut, Dâr İbn Kesîr, 1997.

Usfûr, Câbir, Teârudât el-Hadâse, Meceletu fusûl, el-Mucelled el-evvel, el-aded el-evvel, 1980.

İmâre, Muhammed, et-Tefsîr el-Marksî li'l-İslâm, el-Kahira, Dâru'ş-Şurûk, 1996.

El-Umerî, Ali Mahmud, en-Nisbetu fi'l-Fikri'l-İslâmî, Dâru'n-nuri'l-mubîn, Amman, El-Ürdün.

El-Ğazâmî, Abdullah Muhammed, Hikâyetu'l-Hadâse fi'l-Memleketi'l-Ara- 
biyyeti's-Suûdiyye, el-Merkez es-Sekâfî el-Arabî, ed-Dâru'l-Beydâ, el-Meğrib/ Beyrut-Lubnan, 2004.

İbn Fâris, Ahmed b. Faris Zekeriyya, Mu'cem Mekâyîs el-Luğa, tahkik: Abdusselam Muhammed Harun, Beyrut, Dâru'l-Cîl, 1999.

El-Keramî, Hasan Saîd, el-Hâdî ilâ Luğati'l-Arab, Beyrut, Dâru Lubnan,1991.

Mebrûk, Ali, Mâ verâ te'sîsu'l-Usûl, el-Kâhira, Dâru ru'ye, 2007.

Mesrehî, Fârih, el-Hadâse fî fikri Muhammed Arkon Mukârebe evveliyye, Beyrut, ed-Dâru'l-Arabiyye li'l-Ulûm Nâşirûn, 2006.

El-Medînî Ahmed, es-Samt-el-Hadâse, uzletu'n-nass ve Hertakatu't-Tanzîr, el-Hadâse el-Uhrâ, Mecelletu Kitâbât Muâsıra, Beyrut-Lubnan, Mucelled 5, el-Aded 15, 1993.

El-Merzûkî, Ebu Ya'rib, İşkâliyyetu tecdidi Usûli'l-Fıkh, Dımaşk, Dâru'l-Fikr, 2006.

Mustafa, İbrahim; Zeyyât, Ahmed; Abdulkadir, Hâmid; Neccâr, Muhammed, el-Mu'cem el-Vasît, tahkik: Mecmeu'l-Luğati'l-Arabiyye, Dâru'd-da've, 1980.

İbn Manzur, Muhammed b. Mükrim el-Mısrî, Lisânu'l-arab, Beyrut, Dâru Sâdır, 1990. 